\title{
Filling a public policy gap in Canada: forest certification
}

\author{
by Sarah Jane Fraser ${ }^{1}$
}

\section{ABSTRACT}

With the opening of a policy space between the public's demand for forest regulation and the ability or willingness of governments to fill that demand, forest certification programs have emerged to fill the gap. The Government of Canada supports certification as an assertion of sustainable forest management that can be communicated to buyers of Canadian forest products. The federal government has played several distinct roles during the development and establishment of forest certification in Canada, as expert, landowner, policy-setter, strategic partner and buyer.

Key words: forest certification, Canada, trade, procurement, government

\section{RÉSUMÉ}

Suite à l'ouverture d'un espace politique entre les exigences du public portant sur la réglementation du milieu forestier et la capacité ou le désir des gouvernements de satisfaire celles-ci, les programmes de certification forestière ont connu une croissance permettant de combler cet espace. Le Gouvernement du Canada appuie la certification en tant que preuve de l'aménagement forestier durable qui peut être communiquée aux acheteurs de produits forestiers canadiens. Le gouvernement fédéral a joué plusieurs rôles distinctifs au cours du développement et de la mise en place de la certification au Canada, en tant qu'expert, propriétaire de boisés, rédacteur de politique, partenaire stratégique et acheteur.

Mots clés : certification forestière, Canada, commerce, approvisionnement, gouvernement

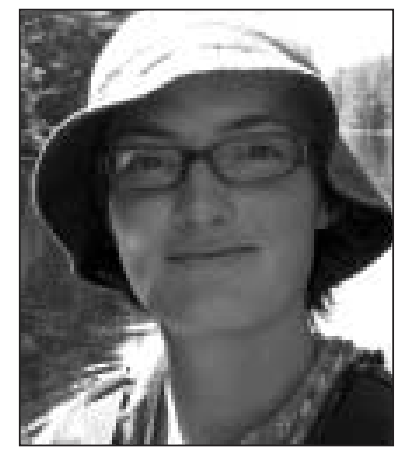

Sarah Jane Fraser

\section{Introduction}

Since the mid 1990s, forest companies have used forest certification as an assurance of sustainable forest management. Implementation of forest certification in Canada has been rapid, with more forest area and forest fibre certified in Canada than in any other country. The quick uptake of certification in this country is due to the efforts of environmental non-governmental organizations, forest companies, forestry professionals, First Nations and other forest communities in Canada along with significant pressure from prominent customers in the USA and overseas. The various levels of government in Canada have also participated in the development and use of forest certification (M. Fullerton ${ }^{2}$, personal communication, 2007).

Fifteen years ago, forest certification was a discussion about what defines sustainable forest management. It has now been mainstreamed in North America and Europe and is found in the language of industry, manufacturers, retailers, banks, non-governmental organizations, and First Nations. Two important drivers of this change have been pressure from environmental groups and the inclusion of forest certification in procurement policies (Domask 2003). In both the

\footnotetext{
$\overline{{ }^{2} \text { Manager, Market Support, Natural Resources Canada - Canadian }}$ Forest Service.
}

public and private spheres, certification is used as a tool to differentiate between forest products.

Along the way, non-state governance of forest resources has emerged and there have been dramatic changes in the way organizations interact with each other and the marketplace.

In Canada, there are three main certification standards in use: the Canadian Standards Association (CSA) standard, the Forest Stewardship Council's (FSC) various regional standards, and the Sustainable Forestry Initiative (SFI) standard. There are several excellent articles and books that deal with the development of forest certification, both in Canada and more broadly (for example Cashore et al. 2004, Jayasinghe et al. 2007, Visseren-Hamakers and Glasbergen 2007). This paper will briefly discuss the widening of the forest policy gap and the role of the federal government in forest certification.

\section{Certification: Changes to the Policy Landscape in Canada}

Twenty-five years ago, the Canadian forest sector, including the industry, various levels of government, environmental groups, and communities, witnessed the creation of a forest policy gap in an unsatisfied public demand for strong regulation of forest practices. The policy gap was caused by faltering international efforts to control forest degradation and changing domestic conditions, combined with pressure from environmental groups for tighter control over forest harvesting. Forest certification addresses this problem by giving buyers a description of the conditions under which forest harvesting takes place. Buyers may then choose a product that comes with this portrait of performance or, in some cases, display a preference between dissimilar certification standards.

1930 Carling Avenue, Ottawa, Ontario K1A 0C5. E-mail: frasersj@agr.gc.ca 
The international community has made an effort to resolve forest issues in the multilateral context, notably through work on Criteria and Indicators in the Montreal and Helsinki Processes, the International Tropical Timber Organization (ITTO), the Forest Law and Governance (FLEG) process and the United Nations Forum on Forests (UNFF). Canadian officials have taken part in these processes to press for improved forest conditions around the world and, through the UNFF, a legally binding instrument. Despite the important role of the ITTO in the initial development of forest certification systems, forest countries have been unable to fill the space between domestic regulations and the demands of the environmental community with the outcomes of multilateral meetings. For example, the UNFF has not yet reached a consensus on whether a treaty on all types of forests would be the best means to achieve comprehensive progress on achieving global sustainable forest management (M. Fullerton, personal communication, 2007).

In the early 1980s, provincial governments began to ask companies to manage to objectives rather than follow the prescriptive command and control policies that were characteristic of earlier decades (Luckert 2005). Provincial and federal efforts with regulated industries, like forest operations, have focussed on cooperative efforts with companies to improve environmental performance, rather than punishment for non-compliance with regulations. The recently released Factual Record on the pulp and paper sector in Canada and logging operations in Ontario by the Commission for Environmental Cooperation is a good case in point (CEC 2006a, b). The report describes the actions of government officials as they attempted to remediate problems with pulp mills and logging operations by encouraging voluntary action from the regulated industries.

It is worthwhile here to pause and think about why states have retreated from the forefront of forest rule-making. Some argue that top-down rules are less effective and less efficient, or that governments are simply less willing to be solely responsible for forests, and that they demand other actors be more responsible (Arts 2002). Perhaps it is because private regulations, like forest certification, circumvent global policy arrangements that are difficult to achieve, and fill in the gaps that governments are either not willing or not able to fill (Visseren-Hamakers and Glasbergen 2007).

During this period of cooperation between government agencies and industry, companies have promoted self-regulation. This action may have inadvertently stripped government officials of necessary credibility, and contributed to the widening gulf between fairly static public policy goals and rapidly changing public expectations.

If we agree with Cashore et al. (2004) Canadian governments, private landowners and industry have in the past seen themselves as the primary rule-makers, with a general understanding between professionals in these domains, and sometimes with organized labour, that the public and environmental groups simply do not have a good understanding of what is actually happening in the woods. Despite this premise, more and more groups external to government and industry have become a part of the decision-making process, especially environmental groups that believe in the inherent value of forests (Luckert 2005). Non-governmental organizations have not only helped to create the demand for policy in the first place, but have also stepped in to fill the gap. A good example of this is the role of non-governmental organizations in the functioning of Land and Resource Management Planning tables in British Columbia (Ministry of Agriculture and Lands 2007). As Nelson and Vertinsky have described (2005), certification gives non-governmental organizations an even stronger footing in the policy process.

In the early 1990s, environmental groups in Canada and around the world turned to markets and forest management certification systems because they were frustrated with the slow progress of the intergovernmental process and unable to effectively influence government policies. Created outside of government, our most familiar rule-maker, forest certification is an excellent example of what Philipp Pattberg (2005) calls the "development of cooperative rule-making by private actors." These new rules have shifted some authority over forests from government to businesses, NGOs, labour groups, and trade associations. Both profit and not-for-profit groups are providing public goods, reducing information costs, and enhancing certainty, in the same way that an international governmental organization would (Pattberg 2005). Non-governmental organizations draw almost all of their influence from public support, even though private foundations provide a large part of the funding of these organizations. The public, in turn, uses NGOs to collect and disseminate information and establish strategies in an age where the actions of an individual voter are insignificant (Keim 2003).

As a form of voluntary action, forest certification has been successful in no small measure because businesses have an incentive, in the form of market access and protection from protest, to be bound by the rules inherent in forest certification standards. However, certification systems, which are private institutions, and its proponents may be crowding out governments from inhabiting the forest policy environment. This is in part due to the nature of NGOs, which are comfortable using technology to facilitate organizing, strategic use of data and communication skills, an expanded scope of membership, and a significant increase in the kind and number of venues in which environmental groups operate to achieve their objectives (Keim 2003).

Additionally, new kinds of organizations have been created to fill the policy gaps, such as the United Kingdom's Central Point of Expertise on Timber Procurement (CPET). The CPET is run by ProForest, a forestry consulting firm that has been contracted to facilitate the adoption of evolving UK policy on public procurement. The CPET process of assessing forest certification standards enables government procurement officers to follow the UK policy (CPET 2007). However, many other groups may also develop purchasing policies based on the CPET system. Because of this phenomenon, and the potential for these policies to spread, forest certification systems compete, and converge, to satisfy CPET's evaluation criterion, including those standards used in Canada.

In Canada, because there is not yet a federal governmentwide policy on the use of forest certification in public procurement, there has not been a need to evaluate the certification systems used in other countries. With the adoption of a policy on green building, and standing offers for paper and furniture by Public Works and Government Service Canada (PWGSC), the Government of Canada may well need to formally address methodologies for differentiating between certification systems and potentially create a body that can fill the same niche as CPET. 


\section{The Federal Response to Forest Certification in Canada}

The federal position on forest certification is that the three systems are functionally equivalent, but not identical, and that it is beneficial to have more than one standard in use in Canada (M. Fullerton personal communication, 2007). Current figures for certified forest area in Canada show that more than 123 million hectares are SFM (sustainable forest management) certified, representing the vast majority of managed forests (Abusow 2007). Certification has proven to be a good way to bring together traditionally antagonistic parties and interests in one forum, and it draws sustainable development into the "core business" of an industry while providing a way to verify commitments (Arts 2002). This section will focus on how the Government of Canada responded to the creation and subsequent evolution of forest certification standards.

The federal government, while supporting the idea of forest certification at the outset, questioned its application to the situation in Canada (M. Fullerton, personal communication, 2007). This was first because certification had been designed to address deforestation in tropical countries, and second, because legislation and regulations already existed to protect Canada's forest resources. In addition, the designed exclusion of governments from certification decision-making bodies and concerns about introducing private governance to public land caused hesitation when forest certification was introduced in the early 1990s. Despite these reservations, the federal government has provided financial as well as in-kind support to assist in the development of certification standards. For example, federal government employees provided techni$\mathrm{cal}$ and scientific expertise to the standards-setting process, including advising on ongoing work into criteria and indicators under the Montreal Process (M. Fullerton, personal communication, 2007).

The quick uptake of forest certification in Canada through the 1990s was a signal to the federal government that companies operating on Crown land were taking the sustainability issue seriously. Due to the debate about which standard provided the best assurance of sustainability or the best protection from direct action, it became necessary by the early 2000 s for the federal government to work with the provinces and industry to ensure that Canadian forest products were not excluded from environmentally sensitive markets. The most significant of these challenges has been to communicate that the forest management and other regulations that backstop forest certification in Canada are among the most stringent in the world (Cashore and McDermott 2004), and that all three certification standards used in Canada are acceptable to the federal government (CFS 2007).

While the Government of Canada has had some success in promoting the sustainability of Canada's forest products with foreign governments, high-profile announcements by catalogue retailers such as Limited Brands and Williams-Sonoma in 2006 illustrated that large companies with valuable brand identities to protect are interested in corporate social responsibility, especially with respect to the source of the paper they use (ForestEthics 2007).

Not surprisingly, the federal government's work on market acceptance has been hampered by strategic communication efforts from non-governmental organizations, along with the unequal promotion of the various certification standards by the certification bodies themselves. For example, the high visibility of the FSC standard has made it a de facto synonym for sustainable forest management certification, while the lack of promotion of the CSA standard means that few consumers know about it.

With the strong and continuing influence of government procurement policies in Europe and green building policies in the US, it is clear that more work is needed to assure customers that certification in Canada complements a strong regulatory presence and helps to demonstrate sustainability and legality.

\section{Understanding Canada's Position on Certification}

Despite the pressure that remains on forest companies to supply certified forest products, and for buyers to choose certified products, certification is not the solution to problems of poor forest management, a point well made by Simula (2006). Most notably, certification has not decreased deforestation in the tropics, arguably its original objective (UNECE/FAO 2005). At this time, the vast majority of certified forests$87 \%$ - are located in the northern hemisphere, and the total area of all certified forests represents only $7.4 \%$ of the world's forests (UNECE/FAO 2005). Notably, many forest products and environmental services "never reach those international markets where certification could matter" (Luckert 2005).

It is not clear that certification has caused significant adjustments in forest management (Siry et al. 2003). If scant resources are available to achieve global environmental goals, making a concerted investment in forest certification is questionable.

In Canada, our forests are by and large a public resource, under shared jurisdiction. Provincial governments are responsible for managing forest lands, while responsibility for federal lands, interprovincial and international issues lies with the federal government. The primary concern of Canada's federal government with respect to certification and procurement relates to international trade rules and access to markets. The Government of Canada favours lower tariffs for forest products and reducing non-tariff barriers. Because the specification of certain types of forest certification systems by foreign governments and businesses can become a non-tariff trade barrier, and due to the difficulties faced by exporters in satisfying numerous different national criteria against which certification systems are assessed, certification of forest products is a cause for concern (Simula 2006).

Government purchasing policies are constrained by rules established under the World Trade Organization, both in the Technical Barriers to Trade Agreement, and, for signatories, the Government Procurement Agreement (GPA). Under the GPA, there is a requirement for non-discrimination against foreign suppliers, along with equal treatment of suppliers, and transparency of policy-making (Brack 2005). A public procurement policy that specified that only FSC-certified wood was acceptable for purchase would exclude $85 \%$ of Canada's supply of certified forest products (Certification Canada 2007), and may be more trade-restrictive than strictly necessary to achieve the government's objectives.

In the $\mathrm{EU}$, the forest product public procurement debate is being driven, in large part, by the implementation of the Forest Law Enforcement, Governance and Trade (FLEGT) Action Plan (Brack 2005). The FLEGT is using voluntary part- 
nership agreements with harvesting countries to link market pressure for legal timber with capacity-building activities in an attempt to lower the illegal and unsustainable import of timber to the EU. The success of this Action Plan relies heavily on the fact that the EU is a major global importer of timber and timber products (Illegal Logging Info 2007). There is no equivalent process in Canada, in part because Canada buys less than $1 \%$ of the tropical timber produced by International Tropical Timber Organization member countries (M. Fullerton, personal communication, 2007). With such small volumes, it is very unlikely that Canada's purchase of tropical timber will help provide adequate pressure to change forest management practices. However, the Government of Canada can and does influence forest governance more broadly through development assistance (CFAN 2007).

Government regulations that comply with World Trade Organization (WTO) rules on non-tariff trade barriers focus on the outcomes of manufacturing processes, rather than non-product-related production and processing methods; in other words, the characteristics of a product that influence that product's performance, not the way that product was made. In many instances, private regulations have been designed to address the processes themselves. Such is the case of certification of forest and fisheries management, and organic agriculture (Korteland 2006). Despite the problems faced by exporters who are required to satisfy the demands of fairly static public and rapidly evolving private regulations, these two approaches are potentially complementary and governments should generally enable, not obstruct, the development of private regulations (WTO 2007).

The Government of Canada has facilitated the growth of private regulations through providing scientific and technical expertise to the development of certification standards, through public support for all three certification systems in use in Canada, and through the adoption of a position that does not favour one standard over another. Canada's position with respect to procurement policies of other governments and major retailers has been to encourage policies that are "least trade-restrictive," meaning policies that are inclusive of all certification systems, including systems under general use in Canada, the FSC, SFI and CSA standards (M. Fullerton, personal communication, 2007).

Finally, because of the demands placed on procurement officers to sort through and rank the many different sustainable forest management standards, a requirement to purchase certified forest products may inadvertently increase the risk of product substitution from wood to plastic, steel and concrete (Simula 2006). There is significant interest in the federal government to develop green purchasing policies (OGGO 2007). It is to the subject of government procurement that we turn next.

\section{Governments as Buyers of Certified Forest Products}

The federal government in Canada has undertaken to facilitate trade and address potential non-tariff barriers, provide financial and in-kind support to forest certification standards development. Although government participation in the development of certification standards was viewed as something of a liability by some certification bodies due to its dual role as a policy-maker and landowner, governments have emerged as a key player in the certification debate because they are an extremely important potential customer of certi- fied forest products. Not only is the federal government the largest public sector purchaser in Canada, but government policies have an "impact on the national economy and the goods and services made available in the market place" (OGGO 2007).

It is because of buying power and the potential for a policy demonstration effect that the federal government in Canada, where more than $90 \%$ of forested lands are publicly owned (CFS 2007), may have more influence as a buyer than landowner, scientific or technical expert when it comes to the ongoing evolution of forest certification schemes.

In 1995, all federal departments were mandated to create sustainable development strategies (CEC 1999). From this beginning, efforts of the federal government to green its own operations have diversified to include sustainable building design, high-performance community heating systems, transportation initiatives, environmentally preferable product labelling, technological innovation and purchasing policies (Plouffe 2003).

Procurement policies are a primary driver of certification (Domask 2003). They are also a pressure point for environmental groups such as the World Wide Fund for Nature (WWF), which promotes the idea of responsible purchasing "to improve the environmental and social performance of the supply base...by continuously increasing the proportion of forest products purchased that contain timber from credibly certified forests" (White and Sarshar 2006). Public procurement policies are directives that apply to purchasing by public bodies and can address forest products such as paper, furniture and building supplies. Procurement policies that specify certified forest products are reinforcing because they enhance the legitimacy of certification systems, whether they are private or public (Cashore et al. 2004).

In most cases, Government purchasing policies avoid ambiguous language regarding forest characteristics, such as endangered, ancient, intact, natural, threatened, and frontier (Bull et al. 2001). However, in at least one case, a federal department has used the term "ancient forest" in a survey of suppliers of paper products (Heritage Canada 2007). Using language like this has serious implications for the way in which forest policy decisions are taken because it is not clear who gets to choose which characteristics of forests are important. In addition, imprecise wording makes implementation of procurement policies difficult because many of these qualitative descriptors are not measured. Finally, non-technical terms may alienate industry stakeholders by implying that sustainable forest management, even ecosystem-based management, is insufficient to satisfy location-specific demands.

Another high-profile example of a federal procurement policy that references forest products, albeit indirectly, is the Public Works and Government Services (PWGSC) policy to build to the LEED (Leadership in Energy and Environmental Design) Gold standard in all new office construction over $\$ 10$ million (PWGSC 2004). The primary reason for adopting this policy was to align the federal government's own operations with the principles of sustainable development. Building materials are one of several factors that influence the life cycle environmental impact of a building.

The LEED standard, because it recognizes only the FSC certification system, has become a major issue for Canadian producers and retailers of forest products and an advantage 
for forest companies that have FSC-certified forest area and chain of custody.

For both examples, paper and wood building materials, the relationship between current best practices and future environmental performance is unclear. Smith et al. (2006) give a good example of this dilemma when comparing the LEED system to a competing green building standard, Green Globes, in light of their mutual purpose, which is to provide an assessment tool for sustainably designed buildings.

Life-cycle assessment (LCA) has become a widely used tool to assess the overall environmental, energy, and health impacts of products, including building. A cursory review of rating criteria in LEED and Green Globes indicates that, in general, life-cycle assessment is not sufficiently addressed in either system. However, it should be noted Green Globes employs a rating criterion that reflects life-cycle thinking and covers the entire life-cycle of building materials, while LEED to date fails to explicitly address LCA.

In practice, PWGSC's policy to use only LEED does not preclude the use of LCA, but it may communicate to stakeholders that the LEED trademark is more important than the fact that another tool may give better environmental results in the long run.

\section{Conclusion}

Forest certification fills an important policy niche, and has been successfully applied in the Canadian context. With more certified forest area than anywhere else, Canada could be the world's largest stable source of certified forest products. This has been achieved through the hard work of many individuals and groups, including the federal government. The position of the Government of Canada has evolved over time, and reflects the federal responsibility to maintain access to markets for Canadian products.

As forest certification standards continue to change in response to changing market conditions, will federal purchasing power be strong enough to influence the evolution of standards? There is growing interest in renewable fuels and potentially an international standard to certify cellulose ethanol production. Will forest certification become one of the tools needed to asses the life cycle environmental impact of new bioproducts?

Finally, federal officials need to work harder to develop good relationships on forest trade issues, including forest certification, with environmental non-government organizations in order to satisfy public demands for environmental performance.

Kraxner (2007) suggests that rather than specifying forest certification schemes in public procurement policies, governments should pursue broader, shared objectives, such as promoting sustainable forest management and decreasing deforestation. This ideal has been pursued by Canadian officials in international fora, including work on an international legally binding instrument on forests (M. Fullerton, personal communication, 2007). The drive to green government operations has opened another avenue within government to pursue sustainable forest management.

Looking ahead, there are many challenges facing the federal government with respect to forests, not the least of which are climate change and land use, which are having a profound impact on the characteristics and viability of forests in Canada. How forest certification can contribute to managing these macro-level problems remains to be seen.

\section{Acknowledgement}

The author would like to thank Nikita Lysenko for research assistance. The views expressed in this paper are those of the author.

\section{References}

Abusow, K. 2007. Certification statistics [online]. Certification Canada. Available at http://www.certificationcanada.org.

Arts, B. 2002. Green Alliances of Business and NGOs: New styles of self-regulation or 'dead-end roads'? Corporate Social Responsibility and Environmental Management. 9: 26-36.

Brack, D. 2005. Public Procurement of Timber: EU member state initiatives for sourcing legal and sustainable timber. Chatham House, London.

Bull, G., S. Hilsson, J. Williams, E. Rametsteiner, T. Hammett and W. Mabee. 2001. Wood Procurement Policy: An analysis of critical issues and stakeholders. The Forestry Chronicle 77(2): 325-340.

Canadian Forest Service (CFS). 2007. About the Canadian Forest Service: Forests and the Economy [online]. Available at http://cfs.nrcan.gc.ca/aboutus/activities\#forestCertification.

Canadian International Development Agency Forestry Advisors Network (CFAN). 2007. Forestry Issues [online]. Available at www. rcfa-cfan.org.

Cashore, B.G., G. Auld and D. Newsom. 2004. Governing through Markets: Forest certification and the emergence of non-state authority. Yale University Press, New Haven, CT.

Cashore, B.G. and C. McDermott. 2004. Global Environmental Forest Policies: Canada as a Constant Case Comparison of Select Forest Practice Regulations. International Forest Resources [online]. Available at http://www.ifor.ca/report.htm.

Central Point of Expertise on Timber (CPET). 2007. History: Background information on policy [online]. Available at http:// www.proforest.net/cpet/about-cpet/history.

Certification Canada. 2007. Certification Status and Intentions December 2006 [online]. Available at http://www.certificationcanada.org/english/status_intentions/status.php.

Commission for Environmental Cooperation (CEC). 1999. Supporting Green Markets: Environmental labelling, certification and procurement schemes in Canada, Mexico and the United States. Secretariat of the Commission for Environmental Cooperation, Montreal, QC [online]. Available at http://www.cec.org/pubs_ docs/documents/index.cfm?varlan=English\&ID=255.

Commission for Environmental Cooperation (CEC). 2006a. Factual Record: Ontario Logging Submission (SEM-02-001) \& (SEM-04-006). Commission for Environmental Cooperation of North America, Montréal (Québec). Available at http://www. cec.org/files/pdf/sem/SEM-02-001-SEM-04-006-FR_en.pdf.

Commission for Environmental Cooperation (CEC). 2006b. Factual Record: Pulp and Paper Submission (SEM-02-003). Commission for Environmental Cooperation of North America, Montréal (Québec). Available at http://www.cec.org/files/pdf/sem/ SEM-02-003-FR_en.pdf.

Domask, J. 2003. From boycotts to global partnership: NGOs, the private sector, and the struggle to protect the world's forests. Chapter 8 in J.P. Doh and H. Teegen (eds.). Globalization and NGOs: Transforming business, government and society. Praeger Publishers.

ForestEthics. 2007. ForestEthics and Limited Brands (Victoria's Secret) Reach Landmark Agreement on Environmental Stewardship (US release) [online]. Available at http://forestethics.com.

Heritage Canada. 2007. Thinking about Ancient Forest Friendly paper [online]. Available at http://www.pch.gc.ca/progs/ac-ca/ progs/padie-bpidp/pubs/2005-2006/aia/preface_e.cfm.

Illegal Logging Info. 2007. FLEGT Overview [online]. Available at http://www.illegal-logging.info/sub_approach.php?approach_id= 26\&subApproach_id=119.

Jayasinghe, P., S.D. Allen, G.Q. Bull and R.A. Kozak. 2007. The Status of Forest Certification in the Canadian Value-Added Wood Products Manufacturing Sector. The Forestry Chronicle 83(1): $113-125$. 
Keim, G. 2003. Nongovernmental Organizations and BusinessGovernment Relations: The importance of Institutions. Chapter 2 in J.P. Doh and H. Teegen (eds.). Globalization and NGOs: Transforming business, government and society. Praeger Publishers. Korteland, M.H. 2006. Eco-labelling: to be or not to be? Desirability of eco-labels from an environmental and poverty perspective [online]. Available at http://www.ce.nl/pdf/ReportMarisa.pdf.

Kraxner, F. 2007. Forest Certification and Certified Forest Products: A market overview for identifying tools to curb illegal forest actions. Background paper prepared for the International Experts Meeting on Illegal Logging, 5-6 March 2007, Tokyo, Japan.

Luckert, M.K. 2005. In Search of Optimal Institutions for Sustainable Forest Management: Lessons from developed and developing countries. Chapter 2 in S. Kant and R.A. Berry (eds.). Institutions, Sustainability, and Natural Resources: Institutions for Sustainable Forest Management. Springer, Dordrecht.

Ministry of Agriculture and Lands. 2007. Land and Resource Management Plans (LRMPs) and Regional Land Use Plans in BC [online]. Available at http://ilmbwww.gov.bc.ca/lup/lrmp/index.html. Nelson, H. and I. Vertinsky. 2005. The International Trade and Environment Regime and the Sustainable Management of Canadian Forests. Chapter 12 in S. Kant and R.A. Berry (eds.). Institutions, Sustainability, and Natural Resources: Institutions for sustainable forest management. Springer, Dordrecht.

Office of Greening Government Operations (OGGO). 2007. Procurement [online]. Available at http://www.greeninggovernment.gc.ca/default.asp?lang=En\&n=256986C5-1.

Pattberg, P. 2005. The Institutionalization of Private Governance: How business and nonprofit organizations agree on transnational rules. Governance: an international Journal of Policy, Administration, and Institutions18(4): 585-610.
Plouffe, M. 2003. Existing Green Procurement Initiatives. Commission for Environmental Cooperation. Available at http://www.cec.org/files/PDF/ECONOMY/Green-Procurement_ Initiatives_en.pdf.

Public Works and Government Services Canada (PWGSC). 2004. PWGSC Greens Government Operations [online]. Available at http://news.gc.ca/web/view/en/index.jsp?articleid=86449.

Simula, M. 2006. Public Procurement Policies for Forest Products and their Impacts. FAO, Rome. Available at http://www.fao.org/ forestry/webview/media?mediaId=11153\&langId $=1$.

Siry, J.P., F.W. Cubbage and M.R. Ahmed. 2003. Sustainable forest management: global trends and opportunities. Forest Policy and Economics 7(4): 551-361.

Smith, T.M., M. Fischlein, S.Suh and P.Huelman. 2006. Green Building Rating Systems: A Comparison Of The Leed And Green Globes Systems In The US. Prepared For: The Western Council of Industrial Workers. Available at http://www.thegbi.org/gbi/Green_ Building_Rating_UofM.pdf.

UNECE/FAO. 2005. Forest Products Annual Market Review. United Nations Economic Commission for Europe/Food and Agriculture Organization of the United Nations, Geneva.

Visseren-Hamakers, I.J. and P. Glasbergen. 2007. Partnerships in Forest Governance. Global Environmental Change. doi:10.1016/ j.gloenvcha.2006.11.003

White, G. and D. Sarshar. 2006. Responsible Purchasing of Forest Products, Second Edition. Global Forest and Trade Network, World Wide Fund for Nature. Washington, DC.

WTO. 2007. Private Sector Standards and Developing Country Exports of Fresh Fruit and Vegetables. G/SPS/GEN/761. 